\title{
DOES FOODSERVICE INDUSTRY CARE ABOUT CSR? A STUDY IN PORTUGAL AND UKRAINE
}

\author{
Oksana Sokil, Iveta Ubrežiová, Teresa Eugenio, Tânia Marques
}

\begin{abstract}
The purpose of the article is to compare the CSR perception level of the food service industry in Portugal and Ukraine. The main goal of the study is to find the attitudes in Portugal and in Ukraine towards CSR. Additionally, two hypotheses were formulated to understand the possible relation between (1) the financial situation and (2) the duration of the company with the awareness level about the CSR concept. A quantitative approach, using questionnaires, was adopted to survey using a sample of 201 representatives of SMEs in the foodservice sector (101 Portuguese and 100 Ukrainian), in 2019. Descriptive statistics and Spearman test were used to analyze the data. The present work demonstrates a significant correlation between the financial situation of the company and the CSR awareness level of leadership. Furthermore, the research shows that activities related to the economic sphere and CSR workplace policy among food sector companies in Ukraine and Portugal are developed to a great extent. From this point of view, we can state, that the publication of the article is one of the results and supported by grant project KEGA 005SPU-4/2019 "Theory and Practice of the International Management and Entrepreneurship in Multicultural Environment". In this study, two different countries were chosen (Portugal and Ukraine), which are different in culture, history, and economic background. The paper focused on the food service industry and contributes to the ongoing debate about the SMEs and its involvement with CSR. It also helps schools to identify plans in CSR policy and topics for future research.
\end{abstract}

Keywords: Corporate Social Responsibility; Food service Industry; SMEs; Portugal; Ukraine

\section{INTRODUCTION}

The social orientation of the world economy requires the development of Corporate Social Responsibility (CSR) activities to ensure the free entry of domestic companies into world markets (Van Marrewijk, 2003) and to increase cooperation with foreign investors, maintaining a worthy competitive position in the international arena (Secchi, 2007; Lee, 2008). The understanding of CSR importance pushes business to assume not only the behavior of law-abidingness but also to carry out voluntary participation in the implementation of corporate contribution to the development of the community, the territory, and establishing social partnership relations with the state (Burja and Mihalache, 2010).

Although there has been an increase in CSR interest at a global scale trying to define CSR is not an easy task (Nyarku and Ayekple, 2019; Aßländer, 2011). First of all, there are different economic traditions in Europe and the US, which results in different interpretations of corporations' responsibilities. The American perspective of the concept is mainly oriented on ethical responsibility and corporate philanthropy (besides economic and legal obligations), while the European perspective sees such responsibilities as the task of government (Kasych, 2014). As defined in ISO 26000 (2010), social responsibility is the responsibility of an enterprise for the impact of its decisions and actions on society, the environment, through transparent and ethical behavior. Moreover, it is necessary to increase the number of studies related to CSR and SMEs (Sweeney, 2007). Companies often lack a clear understanding and conscious recognition that CSR is not something exceptional, caused by special circumstances, but a norm that stems from the very essence of business, the philosophy of management (2016; Kasych, 2014; Kravchenko, 2013). Furthermore, considering the new trend in the literature of describing the relationship between CSR and geography (John et al., 2011; Loughran and Schultz, 2005; Sorenson and Baum, 2003), one can agree with the importance of showing the influence of company's geographical position on the process of CSR strategy formation. Thus, comparative researches on CSR development are needed not only within the neighboring countries but also within the countries which are located in different geographic areas (Branco and Delgado, 2011). 
Thus, this study aims to compare the CSR perception level in the foodservice sector in Portugal and Ukraine. Given the different geographic location and business environment, both countries, Ukraine and Portugal, are ideally suited for the study. It is also worth mentioning that the selected countries have a different cultural, historical, and economic background, which can affect the level of the CSR perception. However, the dynamic development of the food service market in Ukraine and Portugal is a common feature of the studied countries. For example, from the end of 2015 - beginning of 2016, the Portuguese public foodservice market has started to emerge from the crisis, driven by the growth of the tourism industry (GIRA Foodservice, 2017). During the last years, the Ukrainian food service market is as well trying to recover after the political and economic crisis of $2014-2015$. There is an increase in the competition between food establishments, the emergence of new formats, and the use of innovative approaches in the activities of food service enterprises of the country (Hirnyak and Glagola, 2018). The food service market was chosen as the main field of our research based on the before-mentioned facts. Specifically, the main goals of the study are to find the attitudes in Portugal and Ukraine towards CSR: identifying what does motivate food service SMEs to implement the instruments of CSR; what are the main hindrances that food service SMEs face to implement the CSR principles into their business strategies; and what kind of CSR-related activities are commonly carried out by the food service companies in environmental, economic and social pillars of the triple bottom line approach. Additionally, two hypotheses were formulated to understand the possible relation between (1) the financial situation and (2) the duration of the company with the awareness level about the CSR concept.

The rest of the paper is structured as follows. The second section reviews the literature on the context of CSR, including sub-sections to describe the current CSR development in Portugal and Ukraine. The hypotheses are presented in the third section, followed by the methodological issues in terms of the research design and sample identification included in the fourth section. The results are presented in the fifth and are discussed in the sixth section, followed by the conclusion and limitations along with suggestions for further research avenues.

\section{CSR and the specific cases of CSR in Portugal and Ukraine}

Nowadays, the development of a CSR strategy for an enterprise is one of the crucial components for its success. The implementation of CSR principles into company activities leads to a higher level of interconnection with the society. Moreover, it is necessary to underline that CSR is one of the most important factors on the way to economic development for an enterprise, as well as for the country (Ebner and Baumgartner, 2006) and contributes to sustainable development (Behringer and Szegedi, 2016; Kolk and Van Tulder, 2010; Aras and Crowther, 2008). Even though the concept of CSR has emerged within the last century, there is no universal definition of CSR (Duman, Giritli and McDermott, 2016; Ness, 1992). There are already several models in understanding the concept of CSR, like the models of Carroll (1979), Wartick and Cochran (1985), Wood (1991), or Clarkson (1995), the study of Elkington (1999) on the Triple Bottom Line (TBL), measures the three pillars of CSR, economic, environmental and social performance of the organization (Elkington, 1999). The three Ps: (i) profit (i.e., financial), (ii) people (i.e., social), and (iii) the planet (i.e., the environment) are still perceived as synonymous of CSR (Fauzi, Svensson and Rahman, 2010; Rubenstein, 2003).

CSR is being widely developed in the European Union, where companies make voluntary commitments to labor protection, waste management, business ethics while presenting similar requirements to their foreign units and partners (Marushchak, 2012). Portugal, being a member of the European Union, is promoting the development of CSR initiatives, leading to responsible business behaviour, improving the situation on the labour market, the quality of products and services provided by companies, as well as sustaining the development of the country as a whole. CSR in Portugal is determined at a national level and is a policy component of the different ministries (Shevchenko, 2014).

Recent studies using Portuguese samples and context showed that employees who are aware of their company's CSR investment activities tend to make an additional effort in their work and even agree with the fact that CSR practices can lead to more effective company performance (Story and Neves, 2015), for Portuguese consumers environmental CSR practices are much more important than social activities and practices Loureiro et al. (2012). Thus, Portuguese scholars are making a huge research effort into the CSR field. However, there are still great opportunities for expanding and promoting the development of broader and more detailed research in this field and to explore different geographic contexts (Branco and Delgado, 2011).

The Ukrainian scientific literature has been increasing the number of publications related to the CSR sphere annually (Kasych and Yakovenko, 2014; Kostyrko, 2014), despite, in Ukraine, social responsibility is at an early stage of development (Kolyanko and Myronov, 2016). As a result, domestic enterprises often take foreign companies' experience and practice as an example when trying to implement a CSR strategy. The main obstacles to the development and promotion of social responsibility are lack of funds, high tax burden, lack of interest in social responsibility has been suggested in the study of Burkovska and Lunkina (2016). The main trends, barriers, and prospects for CSR developing in Ukraine has been explored as well (Zinchenko and Saprykina, 2017), recommending several steps for the future development in the CSR field, such as the development of a regulatory framework that would facilitate CSR activity, raising the awareness of the National Contact Center for Responsible Business Behavior, implementation of CSR courses into university programs, among others.

\section{Scientific hypothesis}

Social responsibility of business should be considered not only as a way of social stabilization but as an instrument for improving the financial situation of the company. However, the relationship between CSR and the company's financial situation can be positive, negative, or 
neutral. Some studies have concluded a positive correlation between CSR and the company's financial performance (Fauzi and Idris, 2009; Orlitzky and Benjamin, 2001; Simpson and Kohers, 2002; Yefimenko et al., 2014), others show a negative relationship (Patten, 2002) and some neutral relationship as well (McWilliams and Siegel, 2001; Moore, 2001).

Thus, the following hypothesis is suggested: Hypothesis 1: There is a significant correlation between the financial situation of the company and the awareness level about the CSR concept. The duration of the company's existence affects the level of CSR development among its' business units (Okhrimenko and Ivanova, 2015). Researchers believe that companies that are operating for a long time have more experience in the business environment and therefore better understand how to properly implement and use the CSR method. Consequently, newly formed companies demonstrate the lack of CSR management experience and skills. Mostly it happens because business owners do not have a clear understanding of the CSR in the process of strategic development. Moreover, the lack of fast, obvious results from the implementation of the CSR strategy is the barrier of CSR activities development among newly formed companies (Sardak and Shmyhovska, 2017). Thus, the following hypothesis is suggested:

Hypothesis 2: There is a significant correlation between the duration of the company's existence and the awareness level about the CSR concept.

\section{MATERIAL AND METHODOLOGY}

In the present study, it is compared to the development of CSR activities among Portugal a Ukraine food service companies. The objective to identify what does motivate food service SMEs to implement the instruments of CSR, what are the main hindrances that food service SMEs face to implement the CSR principles into their business strategies, and what kind of CSR related activities are commonly carried out by the food service companies in environmental, economic and social pillars of the triple bottom line approach. Additionally, who hypotheses were formulated to understand the possible relation between (1) the financial situation and (2) the duration of the company with the awareness level about the CSR concept, as presented in the previous section.

The research was conducted among the companies of the food sector of Portugal and Ukraine operating in three cities of each country (Portugal: Lisbon, Porto, Faro; Ukraine: Kyiv, Lviv, Odesa). The selection can be explained by the fact that according to Statistics Portugal Web Portal (INE, 2018) and State Statistics Service of Ukraine (UKRSTAT, 2018), the before-mentioned cities are the most visited ones. A questionnaire method was used to collect data in January - February 2019 (Ukraine) and March- April 2019 (Portugal). The questionnaire forms were fulfilled by representatives of executive positions. The communication with the respondents was conducted by sending out an online sample of the questionnaire via e-mail and, in some cases, through personal meetings with the respondents. The questionnaire was developed from a thorough literature review (Zinchenko and Saprykina, 2017), which consisted of
15 questions grouped into 6 parts. The questionnaire includes closed and semi-closed questions:

- Part I: represents formal questions about company activities, such as financial status, the duration of the firm's existence, company size;

- Part II: includes questions that allow estimating level of leadership awareness of CSR notion. This part of the questionnaire allows us to find out factors which hinder CSR implementation and factors which, on the other hand, encourage companies to implement and develop activities in this area;

- Part III, IV and V: allow to evaluate the company's activities in three main CSR pillars: economic pillar; environmental pillar and social pillar;

- Part VI: includes questions regarding the company's plans for further CSR development activities.

The questionnaire adopted Likert scales, in which the respondent expressed the extent of his/her agreement or disagreement with a certain statement, ranging from 1 - "strongly disagree" to 5 - "strongly agree" or 1 - "not dealing with" to 5 - "dealing a lot". To analyze the data, Excel and XLSTAT version 2019.1.3 were used. In order to test the hypotheses, the Spearman correlation coefficient was used.

\section{Statistical analysis}

A total of 201 responses were collected: 101 (in Portugal) and 100 (in Ukraine), from representatives of executive positions in Portuguese and Ukrainian companies. Concerning the Portuguese sample companies, the majority was formed by the small-sized enterprises $(80.2 \%)$ and medium-sized (19.8\%). The company's existence duration was the following: $8.9 \%$ less than 1 year, $24.8 \%$ from 1 to 5 years, $51.5 \%$ from 5 to 10 years and $14.9 \%$ more than 10 years. The majority $(88.1 \%)$ has a domestic or local owner and $11.9 \%$ of the respondents have a domestic owner with a foreign investor. $31 \%$ of respondents declared to have a very good financial situation, $32.7 \%$ - above average, $22.8 \%$ - average and $12.9 \%$ - below average. In the case of 100 Ukrainian enterprises, most of them are small-sized (60\%), and the medium-sized companies (40\%). The company's existence duration was the following: $5 \%$ less than 1 year, $28 \%$ from 1 to 5 years, $47 \%$ from 5 to 10 years and $20 \%$ more than 10 years. $79 \%$ of respondents declared to have a domestic owner, $21 \%$ have a domestic owner with a foreign investor. The majority $(40 \%)$ has a very good financial situation, 22\% - above average, 20\% - average, and $18 \%$ - below average.

\section{RESULTS AND DISCUSSION}

The first questions were aimed to explore the general attitude of the respondents toward CSR. $63.4 \%$ of Portuguese and $61 \%$ Ukrainian respondents declared that they are familiar with the term of CSR. Consequently, it can be stated that the CSR concept is well known for most of the enterprises in the investigated market.

The Likert scale helped us with further investigation of the food service companies. Table 1 explicitly shows the extent to which companies agree or disagree with the following statement: "The representatives of executive positions have a good knowledge of CSR concept and the 
ways of CSR implementation into company's activities". Based on the results, only $16.8 \%$ of Portuguese and $19 \%$ of Ukrainian respondents strongly agree that the company's leadership has a good knowledge of the CSR concept. However, it is worth mentioning that $48.5 \%$ of Portuguese and $35 \%$ of Ukrainian respondents see themselves as a socially responsible enterprise.

Table 2 shows that regardless of the country, almost all respondents indicate moral-ethical reasons $(97 \%$ of Portuguese and Ukrainian respondents), improvement of economic indicators (96\% of Portuguese and Ukrainian respondents), maintaining/increasing of the company's reputation (98\% of Portuguese and $100 \%$ of Ukrainian respondents), increasing of the employee motivation (98\% of Portuguese and $97 \%$ of Ukrainian respondents), increasing/maintaining the level of customers' loyalty (99\% of Portuguese and $95 \%$ of Ukrainian respondents) as the main motivating factors for CSR implementation. It is also worth noting that third-party pressures do not motivate enterprises to implement CSR activities in their businesses.
A weak CSR legislation is one of the main barriers to implement/improve CSR activities among Ukrainian food service companies (78\% of respondents). In turn, the majority of Portuguese respondents $(75.2 \%)$ noted that for them the lack of time is one of the biggest obstacles for CSR implementation. The positive fact is that only a few firms have mentioned that CSR activities are not important for their company (5\% of Ukrainian and $4 \%$ of Portuguese respondents) (Table 3 ).

\section{Economic Pillar}

Table 5 shows that most of the respondents $(851 \%$ of Portuguese and $85 \%$ of Ukrainian companies) implement principles of fair trade while doing their business. Moreover, the majority tends to provide information to the stakeholders (consumers, suppliers) (64.4\% of Portuguese and $73 \%$ of Ukrainian companies) and tends to carry out transparent activities (62.4\% of Portuguese and $72 \%$ of Ukrainian companies). From the other side, considering the ethical principles of trade the sales business innovations related activities are not present among the foodservice companies' activities.

Table 1 Respondents' agreement/disagreement with statements toward CSR.

\begin{tabular}{|c|c|c|c|c|c|c|}
\hline Statement & $\begin{array}{c}\text { Mark } \\
\text { Country }\end{array}$ & $\begin{array}{l}\quad 1- \\
\text { strongly } \\
\text { disagree }\end{array}$ & 2 & 3 & 4 & $\begin{array}{c}5- \\
\text { strongly } \\
\text { agree }\end{array}$ \\
\hline \multirow{2}{*}{$\begin{array}{l}\text { The representatives of executive positions have a good } \\
\text { knowledge of the CSR concept and the ways of its } \\
\text { implementation in the company's activity }\end{array}$} & Portugal & $0 \%$ & $3 \%$ & $37.6 \%$ & $42.6 \%$ & $16.8 \%$ \\
\hline & Ukraine & $0 \%$ & $9 \%$ & $29.0 \%$ & $43.0 \%$ & $19.0 \%$ \\
\hline \multirow{2}{*}{ Our company is a socially responsible company } & Portugal & $0 \%$ & $0 \%$ & $21.8 \%$ & $29.7 \%$ & $48.5 \%$ \\
\hline & Ukraine & $0 \%$ & $1 \%$ & $32.0 \%$ & $32.0 \%$ & $35.0 \%$ \\
\hline
\end{tabular}

Table 2 Factors that motivate/do not motivate a company to implement CSR.

\begin{tabular}{|c|c|c|c|c|}
\hline \multirow[b]{2}{*}{ Factors } & \multicolumn{2}{|c|}{ Portugal } & \multicolumn{2}{|c|}{ Ukraine } \\
\hline & Do not motivate & Motivate & $\begin{array}{c}\text { Do not } \\
\text { motivate }\end{array}$ & Motivate \\
\hline Moral-ethical reasons & $3 \%$ & $97 \%$ & $3 \%$ & $97 \%$ \\
\hline The improving of economic indicators & $4 \%$ & $96 \%$ & $4 \%$ & $96 \%$ \\
\hline Better relationships with investors & $33.7 \%$ & $66.3 \%$ & $50 \%$ & $50 \%$ \\
\hline Better relationships with community & $5 \%$ & $9 \%$ & $26 \%$ & $74 \%$ \\
\hline The maintaining/increasing the company's reputation & $2 \%$ & $98 \%$ & $0 \%$ & $100 \%$ \\
\hline The increasing employee motivation & $2 \%$ & $98 \%$ & $3 \%$ & $97 \%$ \\
\hline The desire of the environment protection & $21.8 \%$ & $78.2 \%$ & $35 \%$ & $65 \%$ \\
\hline Third party pressures (buyers, competitors, suppliers, etc.) & $88.1 \%$ & $11.9 \%$ & $95 \%$ & $5 \%$ \\
\hline The increasing/maintaining the level of customers' loyalty & 1 & $99 \%$ & $5 \%$ & $9 \%$ \\
\hline
\end{tabular}

Table 3 The main barriers to implement/improve company's CSR activities.

\begin{tabular}{ccc}
\hline Factor & \multicolumn{2}{c}{ Country } \\
\cline { 2 - 3 } & Portugal & Ukraine \\
\hline Shortage of knowledge & $24.8 \%$ & $47 \%$ \\
Resources shortage & $39.6 \%$ & $39 \%$ \\
Weak legislation dealing with CSR & $2 \%$ & $78 \%$ \\
Weak employees' motivation & $1 \%$ & $6 \%$ \\
Lack of human resources & $39.6 \%$ & $24 \%$ \\
Time shortage to implement & $75.2 \%$ & $43 \%$ \\
It is not important for the company & $4 \%$ & $5 \%$ \\
\hline
\end{tabular}


Table 4 The evaluation of the environmental pillar.

\begin{tabular}{|c|c|c|c|c|c|c|}
\hline Activity & $\begin{array}{c}\text { Mark } \\
\text { Country }\end{array}$ & $\begin{array}{c}1- \\
\text { not dealing } \\
\text { with }\end{array}$ & 2 & 3 & 4 & $\begin{array}{c}5- \\
\text { dealing } \\
\text { a lot }\end{array}$ \\
\hline \multirow{2}{*}{ Energy saving } & Portugal & $0 \%$ & $27.7 \%$ & $57.4 \%$ & $14.9 \%$ & $0 \%$ \\
\hline & Ukraine & $0 \%$ & $23 \%$ & $50 \%$ & $27 \%$ & $0 \%$ \\
\hline \multirow{2}{*}{ Environmentally friendly work processes } & Portugal & $0 \%$ & $5 \%$ & $44.5 \%$ & $50.5 \%$ & $0 \%$ \\
\hline & Ukraine & $0 \%$ & $2 \%$ & $31 \%$ & $54 \%$ & $13 \%$ \\
\hline \multirow{2}{*}{$\begin{array}{l}\text { Increase employees' knowledge about } \\
\text { environmental protection }\end{array}$} & Portugal & $0 \%$ & $20.8 \%$ & $59.4 \%$ & $19.8 \%$ & $0 \%$ \\
\hline & Ukraine & $0 \%$ & $27 \%$ & $48 \%$ & $22 \%$ & $3 \%$ \\
\hline \multirow{2}{*}{ Minimization of environmental impacts } & Portugal & $1 \%$ & $1 \%$ & $2 \%$ & $30.7 \%$ & $65.3 \%$ \\
\hline & Ukraine & $0 \%$ & $0 \%$ & $1 \%$ & $41 \%$ & $58 \%$ \\
\hline \multirow{2}{*}{$\begin{array}{l}\text { Promoting cooperation with other } \\
\text { companies in the environmental field }\end{array}$} & Portugal & $26.7 \%$ & $49.5 \%$ & $22.8 \%$ & $1 \%$ & $0 \%$ \\
\hline & Ukraine & $27 \%$ & $36 \%$ & $35 \%$ & $2 \%$ & $0 \%$ \\
\hline \multirow{2}{*}{$\begin{array}{l}\text { Purchase of environmentally friendly } \\
\text { machinery and equipment }\end{array}$} & Portugal & $0 \%$ & $17.8 \%$ & $66.3 \%$ & $13.9 \%$ & $2 \%$ \\
\hline & Ukraine & $0 \%$ & $15 \%$ & $36 \%$ & $46 \%$ & $3 \%$ \\
\hline \multirow{2}{*}{ Waste sorting } & Portugal & $0 \%$ & $0 \%$ & $2 \%$ & $31.7 \%$ & $66.3 \%$ \\
\hline & Ukraine & $0 \%$ & $0 \%$ & $6 \%$ & $35 \%$ & $59 \%$ \\
\hline \multirow{2}{*}{$\begin{array}{c}\text { Reducing material and energy-intensive } \\
\text { processes }\end{array}$} & Portugal & $0 \%$ & $12.9 \%$ & $68.3 \%$ & $17.8 \%$ & $1 \%$ \\
\hline & Ukraine & $0 \%$ & $7 \%$ & $41 \%$ & $50 \%$ & $2 \%$ \\
\hline \multirow{2}{*}{$\begin{array}{l}\text { Research and development in the field of } \\
\text { environmental protection }\end{array}$} & Portugal & $60.4 \%$ & $34.6 \%$ & $5 \%$ & $0 \%$ & $0 \%$ \\
\hline & Ukraine & $59 \%$ & $32 \%$ & $9 \%$ & $0 \%$ & $0 \%$ \\
\hline \multirow{2}{*}{ Transport optimization } & Portugal & $0 \%$ & $1 \%$ & $41.6 \%$ & $50.5 \%$ & $6.9 \%$ \\
\hline & Ukraine & $0 \%$ & $7 \%$ & $23 \%$ & $60 \%$ & $10 \%$ \\
\hline \multirow{2}{*}{ Waste minimization } & Portugal & $0 \%$ & $1 \%$ & $41.6 \%$ & $50.5 \%$ & $6.9 \%$ \\
\hline & Ukraine & $0 \%$ & $1 \%$ & $16 \%$ & $50 \%$ & $33 \%$ \\
\hline \multirow{2}{*}{ Water saving } & Portugal & $0 \%$ & $0 \%$ & $25.7 \%$ & $53.5 \%$ & $20.8 \%$ \\
\hline & Ukraine & $0 \%$ & $0 \%$ & $22 \%$ & $54 \%$ & $24 \%$ \\
\hline
\end{tabular}

Table 5 The evaluation of economic pillar.

\begin{tabular}{|c|c|c|c|c|c|c|}
\hline Activity & $\begin{array}{l}\text { Mark } \\
\text { Country }\end{array}$ & $\begin{array}{c}1- \\
\text { not dealing } \\
\text { with }\end{array}$ & 2 & 3 & 4 & $\begin{array}{l}5- \\
\text { dealing } \\
\text { a lot }\end{array}$ \\
\hline \multirow[t]{2}{*}{ Ethical principles in trade } & Portugal & $0 \%$ & $0 \%$ & $1 \%$ & $50.5 \%$ & $48.5 \%$ \\
\hline & Ukraine & $0 \%$ & $0 \%$ & $4 \%$ & $42 \%$ & $54 \%$ \\
\hline \multirow[t]{2}{*}{ Fair trade } & Portugal & $0 \%$ & $0 \%$ & $0 \%$ & $14.9 \%$ & $85.1 \%$ \\
\hline & Ukraine & $0 \%$ & $0 \%$ & $0 \%$ & $15 \%$ & $85 \%$ \\
\hline \multirow{4}{*}{$\begin{array}{l}\text { Innovations in sales business activities taking } \\
\text { into account the ethical principles of trade } \\
\text { Processing of invoices on time }\end{array}$} & Portugal & $52.4 \%$ & $42.6 \%$ & $3 \%$ & $2 \%$ & $0 \%$ \\
\hline & Ukraine & $26 \%$ & $26 \%$ & $40 \%$ & $8 \%$ & $0 \%$ \\
\hline & Portugal & $2 \%$ & $0 \%$ & $0 \%$ & $50.5 \%$ & $47.5 \%$ \\
\hline & Ukraine & $0 \%$ & $0 \%$ & $1 \%$ & $49 \%$ & $50 \%$ \\
\hline \multirow[t]{2}{*}{ Providing benefits to disabled customers } & Portugal & $23.8 \%$ & $37.6 \%$ & $35.6 \%$ & $2 \%$ & $1 \%$ \\
\hline & Ukraine & $17 \%$ & $23 \%$ & $34 \%$ & $26 \%$ & $0 \%$ \\
\hline \multirow{2}{*}{$\begin{array}{l}\text { Providing customer service after the sale of } \\
\text { products and services }\end{array}$} & Portugal & $0 \%$ & $0 \%$ & $5 \%$ & $44.5 \%$ & $50.5 \%$ \\
\hline & Ukraine & $0 \%$ & $0 \%$ & $2 \%$ & $47 \%$ & $51 \%$ \\
\hline \multirow{2}{*}{$\begin{array}{c}\text { Providing information to stakeholders } \\
\text { (consumers, suppliers, ...) }\end{array}$} & Portugal & $0 \%$ & $0 \%$ & $1 \%$ & $34.6 \%$ & $64.4 \%$ \\
\hline & Ukraine & $0 \%$ & $0 \%$ & $0 \%$ & $27 \%$ & $73 \%$ \\
\hline \multirow{2}{*}{$\begin{array}{l}\text { Solving complaints with shareholders, suppliers } \\
\text { and business partners }\end{array}$} & Portugal & $0 \%$ & $0 \%$ & $16.8 \%$ & $37.6 \%$ & $45.6 \%$ \\
\hline & Ukraine & $0 \%$ & $1 \%$ & $10 \%$ & $53 \%$ & $36 \%$ \\
\hline \multirow[t]{2}{*}{ Transparency of company's activities } & Portugal & $0 \%$ & $0 \%$ & $0 \%$ & $37.6 \%$ & $62.4 \%$ \\
\hline & Ukraine & $0 \%$ & $0 \%$ & $2 \%$ & $26 \%$ & $72 \%$ \\
\hline
\end{tabular}




\section{Social Pillar}

Our study results show that most of the workplace policy activities listed in the questionnaire are being implemented to a high extent (Table 6). Regarding the overall view of the workplace policy (social pillar), respondents, regardless of the location, are trying to implement a considerable number of such activities: compliance with labour standards (Portuguese respondents - 95\%, Ukrainian respondents - 95\%); respect for human rights and freedoms (Portuguese respondents $-73.3 \%$, Ukrainian respondents $-88 \%$ ); safety and protection of health at the workplace (Portuguese respondents - 80\%, Ukrainian respondents - 93\%).

Another area of the social pillar (policy towards community) has a paradoxically low development level. Ukrainian companies cooperate with the public community only through non-financial contributions supporting the local community (38\%). On the other hand, Portuguese companies support the community by helping in the organization of different events (33.7\%) (Table 7).

\section{Concluding Questions About CSR}

The basic aim of this part is to examine the plans in CSR policy of the investigated companies.

The vast majority of the companies $(79.2 \%$ of Portuguese and $91 \%$ of Ukrainian) is planning to increase CSR related activities in the next 3 years. It should be noted that none of the respondents expressed a desire to reduce the number of CSR related measures.

\section{Testing the hypotheses}

Analyzing the correlation between the financial situation of the company and the CSR concept awareness level among Portuguese and Ukrainian foodservice companies,

Table 6 The evaluation of the workplace policy (social pillar).

\begin{tabular}{|c|c|c|c|c|c|c|}
\hline Activity & $\begin{array}{l}\text { Mark } \\
\text { Country }\end{array}$ & $\begin{array}{c}1- \\
\text { not dealing } \\
\text { with }\end{array}$ & 2 & 3 & 4 & $\begin{array}{c}5- \\
\text { dealing } \\
\text { a lot }\end{array}$ \\
\hline \multirow{3}{*}{$\begin{array}{l}\text { Anti-corruption and } \\
\text { bribery standards } \\
\text { Awareness of } \\
\text { employees about } \\
\text { important matters } \\
\text { relating to the } \\
\text { company }\end{array}$} & $\begin{array}{l}\text { Portugal } \\
\text { Ukraine }\end{array}$ & $\begin{array}{l}0 \% \\
0 \%\end{array}$ & $\begin{array}{l}0 \% \\
0 \%\end{array}$ & $\begin{array}{l}10.9 \% \\
13 \%\end{array}$ & $\begin{array}{l}63.4 \% \\
57 \%\end{array}$ & $\begin{array}{c}25.7 \% \\
30 \%\end{array}$ \\
\hline & Portugal & $0 \%$ & $1 \%$ & $33.7 \%$ & $54.4 \%$ & $10.9 \%$ \\
\hline & Ukraine & $0 \%$ & $0 \%$ & $26 \%$ & $59 \%$ & $15 \%$ \\
\hline Compliance with & Portugal & $0 \%$ & $0 \%$ & $0 \%$ & $5 \%$ & $95 \%$ \\
\hline labour standards & Ukraine & $0 \%$ & $0 \%$ & $0 \%$ & $8 \%$ & $92 \%$ \\
\hline $\begin{array}{l}\text { Development of } \\
\text { qualification, skills, }\end{array}$ & Portugal & $0 \%$ & $0 \%$ & $37.6 \%$ & $37.6 \%$ & $24.8 \%$ \\
\hline $\begin{array}{l}\text { and long-lasting career } \\
\text { of its employees }\end{array}$ & Ukraine & $0 \%$ & $1 \%$ & $30 \%$ & $42 \%$ & $27 \%$ \\
\hline \multirow{2}{*}{$\begin{array}{l}\text { Employee loyalty to } \\
\text { the company }\end{array}$} & Portugal & $0 \%$ & $5 \%$ & $43.6 \%$ & $35.6 \%$ & $15.8 \%$ \\
\hline & Ukraine & $0 \%$ & $1 \%$ & $47 \%$ & $47 \%$ & $5 \%$ \\
\hline \multirow{2}{*}{ Fair wage } & Portugal & $0 \%$ & $0 \%$ & $0 \%$ & $33.7 \%$ & $66.3 \%$ \\
\hline & Ukraine & $0 \%$ & $0 \%$ & $0 \%$ & $39 \%$ & $61 \%$ \\
\hline \multirow{4}{*}{$\begin{array}{l}\text { Helping workers and } \\
\text { their families } \\
\text { Protection of an } \\
\text { intellectual property }\end{array}$} & Portugal & $1 \%$ & $33.7 \%$ & $56.4 \%$ & $8.9 \%$ & $0 \%$ \\
\hline & Ukraine & $1 \%$ & $21 \%$ & $60 \%$ & $18 \%$ & $0 \%$ \\
\hline & Portugal & $0 \%$ & $39.6 \%$ & $59.4 \%$ & $1 \%$ & $0 \%$ \\
\hline & Ukraine & $1 \%$ & $34 \%$ & $64 \%$ & $1 \%$ & $0 \%$ \\
\hline \multirow{2}{*}{$\begin{array}{l}\text { Protection of specific } \\
\text { groups of employees } \\
\text { (as disabled, ...) }\end{array}$} & Portugal & $5 \%$ & $37.6 \%$ & $55.4 \%$ & $2 \%$ & $0 \%$ \\
\hline & Ukraine & $1 \%$ & $20 \%$ & $64 \%$ & $15 \%$ & $0 \%$ \\
\hline $\begin{array}{l}\text { Providing space for } \\
\text { mental hygiene (as }\end{array}$ & Portugal & $0 \%$ & $0 \%$ & $9 \%$ & $45.5 \%$ & $45.5 \%$ \\
\hline $\begin{array}{c}\text { rest, nutrition, } \\
\text { regeneration area, ...) }\end{array}$ & Ukraine & $0 \%$ & $0 \%$ & $1 \%$ & $63 \%$ & $36 \%$ \\
\hline Respect for human & Portugal & $0 \%$ & $0 \%$ & $0 \%$ & $26.7 \%$ & $73.3 \%$ \\
\hline rights and freedoms & Ukraine & $0 \%$ & $0 \%$ & $0 \%$ & $12 \%$ & $88 \%$ \\
\hline \multirow{2}{*}{$\begin{array}{l}\text { Safety and protection } \\
\text { of health in the } \\
\text { workplace }\end{array}$} & Portugal & $0 \%$ & $0 \%$ & $0 \%$ & $20 \%$ & $80 \%$ \\
\hline & Ukraine & $0 \%$ & $0 \%$ & $0 \%$ & $7 \%$ & $93 \%$ \\
\hline $\begin{array}{l}\text { Work benefits (e.g. } \\
\text { Home office, }\end{array}$ & Portugal & $0 \%$ & $0 \%$ & $20.8 \%$ & $29.7 \%$ & $49.5 \%$ \\
\hline $\begin{array}{c}\text { additional insurance, } \\
\ldots \text {..) }\end{array}$ & Ukraine & $0 \%$ & $1 \%$ & $22 \%$ & $44 \%$ & $33 \%$ \\
\hline $\begin{array}{c}\text { Work-life balance of } \\
\text { employees }\end{array}$ & $\begin{array}{l}\text { Portugal } \\
\text { Ukraine } \\
\end{array}$ & $\begin{array}{l}0 \% \\
0 \% \\
\end{array}$ & $\begin{array}{l}0 \% \\
0 \% \\
\end{array}$ & $\begin{array}{c}14.8 \% \\
11 \% \\
\end{array}$ & $\begin{array}{c}31.7 \% \\
42 \% \\
\end{array}$ & $\begin{array}{c}53.5 \% \\
47 \% \\
\end{array}$ \\
\hline
\end{tabular}


Table 7 The evaluation of the policy towards the community (social pillar).

\begin{tabular}{|c|c|c|c|c|c|c|}
\hline Activity & $\begin{array}{l}\text { Mark } \\
\text { Country }\end{array}$ & $\begin{array}{l}1- \\
\text { not dealing } \\
\text { with }\end{array}$ & 2 & 3 & 4 & $\begin{array}{l}5- \\
\text { dealing } \\
\text { a lot }\end{array}$ \\
\hline \multirow{2}{*}{$\begin{array}{l}\text { Participation and membership in various } \\
\text { associations that support the development of the } \\
\text { local community }\end{array}$} & Portugal & $8 \%$ & $38.6 \%$ & $52.4 \%$ & $1 \%$ & $0 \%$ \\
\hline & Ukraine & $6 \%$ & $27 \%$ & $45 \%$ & $21 \%$ & $1 \%$ \\
\hline \multirow{2}{*}{$\begin{array}{l}\text { Providing financial contributions to support the } \\
\text { local community }\end{array}$} & Portugal & $1 \%$ & $40.6 \%$ & $51.5 \%$ & $6.9 \%$ & $0 \%$ \\
\hline & Ukraine & $1 \%$ & $38 \%$ & $45 \%$ & $15 \%$ & $1 \%$ \\
\hline \multirow{2}{*}{$\begin{array}{l}\text { Providing non-financial contributions to support } \\
\text { the local community }\end{array}$} & Portugal & $0 \%$ & $7.9 \%$ & $48.5 \%$ & $38.6 \%$ & $5 \%$ \\
\hline & Ukraine & $0 \%$ & $3 \%$ & $19 \%$ & $40 \%$ & $38 \%$ \\
\hline \multirow{2}{*}{$\begin{array}{c}\text { Purchase of raw materials and resources from } \\
\text { local businesses }\end{array}$} & Portugal & $0 \%$ & $5 \%$ & $59.4 \%$ & $35.6 \%$ & $0 \%$ \\
\hline & Ukraine & $0 \%$ & $7 \%$ & $61 \%$ & $26 \%$ & $6 \%$ \\
\hline \multirow{2}{*}{$\begin{array}{l}\text { Support to the children and youth education in } \\
\text { the local community }\end{array}$} & Portugal & $1 \%$ & $17.8 \%$ & $44.6 \%$ & $30.7 \%$ & $5.9 \%$ \\
\hline & Ukraine & $0 \%$ & $1 \%$ & $30 \%$ & $41 \%$ & $28 \%$ \\
\hline \multirow{2}{*}{$\begin{array}{l}\text { Support to the local community after natural } \\
\text { disasters }\end{array}$} & Portugal & $6 \%$ & $78.2 \%$ & $14.8 \%$ & $1 \%$ & $0 \%$ \\
\hline & Ukraine & $17 \%$ & $51 \%$ & $30 \%$ & $2 \%$ & $0 \%$ \\
\hline \multirow{2}{*}{$\begin{array}{l}\text { Supporting the community in the organization of } \\
\text { events (cultural, sports, ...) }\end{array}$} & Portugal & $0 \%$ & $2 \%$ & $29.7 \%$ & $34.6 \%$ & $33.7 \%$ \\
\hline & Ukraine & $0 \%$ & $5 \%$ & $34 \%$ & $33 \%$ & $28 \%$ \\
\hline \multirow{2}{*}{$\begin{array}{l}\text { Conducting a systematic questionnaire survey } \\
\text { about the company's activity }\end{array}$} & Portugal & $11.9 \%$ & $25.7 \%$ & $48.5 \%$ & $12.9 \%$ & $1 \%$ \\
\hline & Ukraine & $21 \%$ & $32 \%$ & $35 \%$ & $12 \%$ & $0 \%$ \\
\hline \multirow{2}{*}{ Creating a job positions in the region } & Portugal & $2 \%$ & $49.5 \%$ & $47.5 \%$ & $1 \%$ & $0 \%$ \\
\hline & Ukraine & $5 \%$ & $33 \%$ & $60 \%$ & $2 \%$ & $0 \%$ \\
\hline
\end{tabular}

Table 8 Correlation matrix according to Spearman's correlation (H1).

\begin{tabular}{ccc}
\hline Variables & $\begin{array}{c}\text { Financial situation of the } \\
\text { company in last three } \\
\text { years }\end{array}$ & $\begin{array}{c}\text { The level of CSR concept } \\
\text { awareness }\end{array}$ \\
\hline \multicolumn{2}{c}{ Portugal } \\
\hline $\begin{array}{c}\text { Financial situation of the company in last three years } \\
\text { The level of CSR concept awareness }\end{array}$ & 1 & $0.788^{*}$ \\
\hline & Ukraine \\
\hline & $0.788^{*}$ & $0.855^{*}$ \\
\hline $\begin{array}{c}\text { Financial situation of the company in last three years } \\
\text { The level of CSR concept awareness }\end{array}$ & $0.855^{*}$ \\
\hline
\end{tabular}

Note: $*<0.0001$.

using the Spearman's correlation test, results are statistically significant correlated $(p=0.001, p<0.05)$, for both Ukrainian and Portuguese samples. Regardless of the country, there is a significant positive relationship between the two variables (Table 8). Thus, it can be concluded that $\mathrm{H} 1$ is confirmed.

\section{Results}

In this study, we have compared the level of CSR perception in Portugal and Ukraine, aiming to explore the main factors influencing the CSR perception level among the foodservice companies in both countries. The results of the study show that despite the different economic, cultural conditions, and even different geographic position of Ukraine and Portugal, respondents from both countries demonstrate a similar CSR perception level and are implementing almost identical activities in relation to CSR, contrary to previous findings from the literature that assumed that the geographic position of the company influences CSR perception level (Boeprasert, 2012; John et al., 2011; Loughran and Schultz, 2005; Sorenson and Baum, 2003).
The respondents" answers to "what are the main hindrances that foodservice SMEs face to implement the CSR principles into their business strategies?" help us to understand that Portuguese and Ukrainian respondents have different perceptions of the barriers on the way of implementing/improving CSR activities. Limited implementation time is the main barrier on the way of the CSR activities implementation among the majority of Portuguese respondents. On the other hand, Ukrainian respondents pointed out that weak CSR legislation and low awareness of CSR are the main barriers to CSR realization. These facts support previous literature that claimed that the lack of knowledge on CSR is the most significant barrier for CSR implementation/improving activities (Kovach, 2013). Also, other authors are dealing with this problem from several sides like Janošková and Csikósová (2019) and Halasi et al. (2019).

The respondents' answers "what does motivate foodservice SMEs to implement the instruments of CSR?", give a possibility to figure out which factors motivate/do not motivate companies to implement CSR policy. Almost all respondents indicated that moral-ethical reasons, 
economic indicators improvement, better relationships with the community, maintaining/increasing of the company's reputation, increasing employees' motivation, increasing/maintaining customers' loyalty level are the most common factors that motivate companies to implement CSR activities. It is also worth saying that third-party pressures do not motivate enterprises to implement CSR activities in their business. These results support previous literature findings that claimed that the possibility of economic indicators improvement is a strong motivator for companies in CSR implementation activities (Simpson and Kohers, 2002; Yefimenko et al., 2014).

The respondents' answers to "what kind of CSR-related activities are commonly carried out by the food service companies?", show that minimization of the impact on the environment and waste sorting is the most common activity from the listed in the questionnaire. As for the economic pillar of CSR, the respondents show the high implementation level of almost all measures in this direction. This situation can be explained by the fact that such kind of activities help the companies to increase the profit, to improve financial and economic indicators, which is the main task for any enterprise. The study shows that companies have a well-developed policy at the workplace. Most respondents have a fair salary system, demonstrate compliance with labor standards, human rights, and freedom protection. Based on this we can sum up that companies understand that a successful business can be built only with the help of skilled workers who need to have a proper working condition. On the other hand, the social pillar (policy towards community) has a paradoxically low development level. In general, Portuguese and Ukrainian foodservice companies are usually engaged in the implementation of similar activities in all three CSR directions. This study also confirmed that enterprises choose activities that are low-priced or easy to implement (Kolyanko and Myronov, 2016). Only measures that are regulated by law are implemented on a high level (such as fair trade, compliance with labor standards, etc.).

The present study claims that there is a significant correlation between the financial situation of the company and the awareness level of executive positions representatives about the CSR concept. Indeed, companies with a better financial situation demonstrate a higher level of awareness of the CSR concept and the ways of its implementation in the company's activities, corroborating our hypothesis 1. This conclusion supports previous literature findings that claimed a positive relationship between awareness of the importance of the CSR activities and the financial situation of the company (Fauzi and Idris, 2009; Orlitzky and Benjamin, 2001; Simpson and Kohers, 2002; Yefimenko et al., 2014). On the other hand, results disprove the fact that the duration of the company's existence influences the company's leadership awareness of CSR concept (Okhrimenko and Ivanova, 2015; Sardak and Shmyhovska, 2017), not corroborating our Hypothesis 2.

\section{CONCLUSION}

This study shows evidence that CSR practices in the environmental and social pillars are poorly developed compared to the other activities of the companies of our sample. Here the attention could be paid more to the privileges or so-called bonuses for companies that are trying to save energy, reduce the materials used, implement energy-intensive processes. Furthermore, the creation of the database on the local level that will clearly show regional requirements for social investments, promote social responsibility and help community development would be a great effective solution on the way of CSR implementation.

The empirical research findings of this study confirm a significant part of the literature review and help us to make important assumptions. The present work demonstrates a significant correlation between the financial situation of the company and the CSR awareness level of leadership. Furthermore, the research shows that activities related to the economic sphere and CSR workplace policy among food sector companies in Ukraine and Portugal are developed to a high extent.

Some limitations can be pointed out. Firstly, the sample is focused on one single industry, the food sector. Future studies could explore CSR perception and awareness in other business sectors with distinct features. Secondly, this study was conducted in Ukraine and Portugal only. Future research could focus on the CSR perception level of companies from countries located in different geographical areas, as outside of Europe. Thirdly, the questionnaire sample has a limited list of measures related to each of the CSR pillars. We suggest that future studies try to explore other CSR activities related to the environmental, economic and, social areas.

\section{REFERENCES}

Aras, G., Crowther, D. 2008. Governance and sustainability. Management Decision, vol. 46, no. 3, p. 433-448. https://doi.org/10.1108/00251740810863870

Aßländer, M. S. 2011. Corporate Social Responsibility as a subsidiary co-responsibility: a macroeconomic perspective. Journal of Business Ethics, vol. 99, no. 1, p. 115-128. https://doi.org/10.1007/s10551-011-0744-X

Behringer, K., Szegedi, K. 2016. The role of CSR in achieving sustainable development-theoretical approach. European Scientific Journal, vol. 12., no. 22, p. 10-25. https://doi.org/10.19044/esj.2016.v12n22p10

Branco, M. C., Delgado, C. 2011. Research on corporate social responsibility and disclosure in Portugal. Social Responsibility Journal, vol. 7, no. 2, p. 202-217. https://doi.org/10.1108/13563280610680821

Boeprasert, A. 2012. Does geographical proximity affect corporate social responsibility? Evidence from the U.S. market. International Business Research, vol. 5, no. 9, p. 138147. https://doi.org/10.5539/ibr.v5n9p138

Burja, V., Mihalache, S. S. 2010. Corporate Social Responsibility. Example Rosia Montana Gold Corporation. Annales Universitatis Apulensis Series Oeconomica, vol. 2, no. 12 , p. 523-532.

Burkovska, A., Lunkina, T. 2016. Zakonodavche rehulyuvannya korporatyvnoyi sotsial'noyi vidpovidal'nosti v Ukrayini potrebuye udoskonalennya. (Legislation regulating corporate social responsibility in Ukraine needs 
improvement). Halytsky Economic Bulletin, vol. 50, no. 1, p. 32-37. (In Ukrainain)

Carroll, A. B. 1979. A three-dimensional conceptual model of corporate social performance. Academy of management review, vol. 4, no. 4, p. 497-505. https://doi.org/10.5465/amr.1979.4498296

Clarkson, M. B .E. 1995. A stakeholder framework for analyzing and evaluating corporation social performance. Academy of management review, vol. 20, no. 1, p. 92-117. https://doi.org/10.5465/amr.1995.9503271994

Duman, U. D., Giritli, H., McDermott, P. 2016. Corporate social responsibility in the construction industry: A comparative study between the UK and Turkey. Built Environment Project and Asset Management, vol. 6, no. 2, p. 218-231. https://doi.org/10.1108/BEPAM-08-2014-0039

Ebner, D., Baumgartner, R. J. 2006. The relationship between sustainable development and corporate social responsibility. Corporate Responsibility Research Conference. Queens University, Belfast, Dublin, vol. 8, no. 1, p. 61-82. https://doi.org/10.21463/jmic.2019.08.1.06

Elkington, J. 1999. Partnerships from cannibals with forks: The triple bottom line of 21st-century business. Enviromental Quality Management, vol. 8, no. 1, p. 37-51. https://doi.org/10.1002/tqem.3310080106

Fauzi, H., Idris, K. 2009. The relationship of CSR and financial performance: new evidence from Indonesian companies. Issues in Social and Environmental Accounting, vol. 3, no. 1, p. 1-24. https://doi.org/10.22164/isea.v3i1.38

Fauzi, H., Svensson, G., Rahman, A. A. 2010. "Triple bottom line" as "Sustainable corporate performance": A proposition for the future. Sustainability, vol. 2, no. 5, p. 1345-1360. https://doi.org/10.3390/su2051345

GIRA Foodservice. 2017. Portuguese foodservice market 2017. Available at: http://www.girafoodservice.com/en/publications/2018/138/fo odservice_portugal_2017.php.

Halasi, D., Schwarcz, P., Mura, L., Roháčiková, O. 2019. The impact of EU support resources on business success of family-owned businesses. Potravinarstvo Slovak Journal of Food Sciences, vol. 13, no. 1, p. 846-853. https://doi.org/10.5219/1167

Hirnyak, L. I., Glagola, V. A. 2018. Suchasnyy stan, perspektyvy ta tendentsiyi rozvytku restorannoho hospodarstva v Ukrayini. (Current state, prospects and trends in the restaurant industry in Ukraine). Economics and Business Management, vol. 16, p. 71-78. Available at: http://market-infr.od.ua/journals/2018/16_2018_ukr/13.pdf.

(In Ukrainian)

INE. 2018. Statistics Portugal - Web Portal. Available at: https://www.ine.pt/xportal/xmain?xpgid=ine_main\&xpid=IN E\&xlang=en.

ISO 26000. 2010. Guiadance on social responsibility, Available

https://www.iso.org/obp/ui/\#iso:std:iso:26000:ed-1:v1:en.

Janošková, M., Csikósová, A. 2019. Corporate culture as one of the factors of global management in multinational companies. In 3rd International Conference: proceedings Poprad Current trends and challenges in businesses management. Ružomberok, Slovakia : VERBUM, p. 241-249. ISBN 978-80-561-0671-6.

John, K., Knyazeva, A., Knyazeva, D. 2011. Does geography matter? Firm location and corporate payout policy. Journal of Financial Economics, vol. 101, no. 3, p. 533-551. https://doi.org/10.1016/j.jfineco.2011.03.014

Kasych, A. 2014. Vtilennya kontseptsiyi stratehichnoho upravlinnya $\mathrm{V}$ praktyku vitchyznyanykh pidpryyemstv.
(Implementation of the concept of strategic management in the practice of domestic enterprises). Business Inform., vol. 11, p. 290-294. (In Ukrainian)

Kasych, A. O., Yakovenko, Y. Y. 2014. Zvit pro stiykyy rozvytok yak analitychnyy instrument formuvannya korporatyvnoyi sotsial'noyi vidpovidal'nosti (The report on the stick flow as an analytical tool for the formation of corporate social responsibility). Effective Economics, vol. 10. (In Ukrainian)

Kolk, A., Van Tulder, R. 2010. International business, corporate social responsibility and sustainable development. International Business Review, vol. 19, no. 2, p. 119-125. https://doi.org/10.1016/j.ibusrev.2009.12.003

Kolyanko, O. V., Myronov, Y. B. 2016. Sotsial'na vidpovidal'nist' u turystychnomu biznesi (Social visibility in the tourism business). In 12th International Scientific and Practical Conference: proceedings. Modern Problems of Management. Kiev : National Aviation University, p. 42-43. (In Ukrainian)

Kostyrko, R. O. 2014. Perspektyvy mizhnarodnoyi intehrovanoyi zvitnosti (Prospects for international integrated reporting). Bulletin of the National University Lviv Polytechnic. Management and entrepreneurship in Ukraine: the stage of formation and problems of development, vol. 794, p. 181-187. (In Ukrainian)

Kovach, M. 2013. Formuvannya stratehichnoho potentsialu pidpryyemstva (Formation of strategic potential of the enterprise). Scientific Bulletin NLTU Ukraine, vol. 23, no. 10, p. 207-212. (In Ukrainian)

Kravchenko, V. 2013. Menedzhment: Navchal'nyy posibnyk (Management: Navchalnyymanual). Odesa : Atlant. (In Ukrainian)

Lee, M. D. P. 2008. A review of the theories of corporate social responsibility: Its evolutionary path and the road ahead. International Journal of Management Reviews, vol. 10, no. 1, p.53-73. https://doi.org/10.1111/j.1468-2370.2007.00226.x

Loughran, T., Schultz, P. 2005. Liquidity: Urban versus rural firms. In Journal of Financial Economics, vol. 78, no. 2, p. 341-374. https://doi.org/10.1016/j.jfineco.2004.10.008

Loureiro, S. M. C., Sardinha, I. M. D., Reijnders, L. 2012. The effect of corporate social responsibility on consumer satisfaction and perceived value: the case of the automobile industry sector in Portugal. Journal of Cleaner Production, vol. $37, \quad$ p. $\quad 172-178$. https://doi.org/10.1016/j.jclepro.2012.07.003

Marushchak, N. V. 2012. Teoriyi korporatyvnoyi sotsial'noyi vidpovidal'nosti u svitoviy praktytsi. (Theories of Corporate Social Responsibility in practice). Current problems of international relations, vol. 111, no. 2, p. 209219. (In Ukrainian)

McWilliams, A., Siegel, D. 2001. Corporate Social Responsibility: a theory of firm perspective. Academy of Management Review, vol. 26, no. 1, p. 117-127. https://doi.org/10.5465/amr.2001.4011987

Moore, G. 2001. Corporate social and financial performance: an investigation in the UK supermarket industry. Journal of Business Ethics, vol. 34, no. 3/4, p. 299315. https://doi.org/10.1023/A:1012537016969

Ness, M. R. 1992. Corporate social responsibility. British Food Journal, vol. 94, no. 7, p. 38-44. https://doi.org/10.1108/00070709210019022

Nyarku, K. M., Ayekple, S. 2019. Influence of corporate social responsibility on non-financial performance. Social Responsibility Journal, vol. 15, no. 7, p. 910-923. https://doi.org/10.1108/SRJ-04-2017-0059 
Okhrimenko, O. O., Ivanova, T. V. 2015. Sotsial'na vidpovidal'nist' (Social visibility). Educational bulletin. National Technological University of Ukraine. Kiev : Polytechnic Institute. (In Ukrainian)

Orlitzky, M., Benjamin, J. D. 2001. Corporate social performance and firm risk: a meta-analytic review. Business \& Society, vol. 40, no. 4, p. 369-396. https://doi.org/10.1177/000765030104000402

Patten, D. M. 2002. The relation between environmental performance and environmental disclosure: a research note. Accounting Organizations and Society, vol. 27, no. 8, p. 763773. https://doi.org/10.1016/S0361-3682(02)00028-4

Rubenstein, R. 2003. A keynote: triple bottom line investing. International Journal of Business Performance Management, vol. 5, no. 2, p. 109-113. https://doi.org/10.1504/IJBPM.2003.003272

Sardak, S., Shmyhovska, O. H. 2017. Aktyvizatsiya zakhodiv korporatyvnoyi sotsial'noyi vidpovidal'nosti v ukrayins'komu biznes-seredovyshchi: motyvy, problemy ta napryamy. (Activation of visiting corporate social visibility in the Ukrainian business environment: motives, problems and directions). Economics and management of national economy, vol. 11, p. 11-16. (In Ukrainian)

Secchi, D. 2007. Utilitarian, managerial and relational theories of corporate social responsibility. International Journal of Management Reviews, vol. 9, no. 4, p. 347-373. https://doi.org/10.1111/j.1468-2370.2007.00215.x

Sweeney, L. 2007. Corporate social responsibility in Ireland: barriers and opportunities experienced by SMEs when undertaking CSR. Corporate Governance, vol. 7, no. 4, p. 516-523. https://doi.org/10.1108/14720700710820597

Shevchenko, O. V. 2014. Rehulyuvannya polityky korporatyvnoyi sotsial'noyi vidpovidal'nosti: praktyka krayinchleniv yevropeys'koho soyuzu. (Regulation of corporate social responsibility: Practice of the EU countries). Current problems of the internatioanl relations, vol. 122, no. 1, p. 1221. (In Ukrainian)

Simpson, W. G., Kohers, T. 2002. The Link Between Corporate Social and Financial Performance: Evidence from the Banking Industry. Journal of Business Ethics, vol. 35, no. 2, p. 97-109. https://doi.org/10.1023/A:1013082525900

Sorenson, O., Baum, J. A. C. 2003. Editors' Introduction: Geography and Strategy: The strategic management of space and place. Geography and Strategy (Advances in Strategic Management). Bingley : Emerald Group Publishing Limited, vol. 20 , p. 1-19. https://doi.org/10.1016/S07423322(03)20016-4

Story, J., Neves, P. 2015. When corporate social responsibility (CSR) increases performance: exploring the role of intrinsic and extrinsic CSR attribution. Business Ethics: A European Review, vol. 24, no. 2, p. 111-124. https://doi.org/10.1111/beer.12084

UKRSTAT. 2018. State Statistics Service of Ukraine, available at: https://ukrstat.org/en.

Van Marrewijk, M. 2003. Concepts and Definitions of CSR and Corporate Sustainability: Between Agency and Communion. Journal of Business Ethics, vol. 44, no. 2-3, p. 95-105. https://doi.org/10.1023/A:1023331212247
Wartick, S. L., Cochran, P. L. 1985. The evolution of the corporate social performance model. Academy of management review, vol. 10, no. 4, p. 758-769. https://doi.org/10.1016/j.bushor.2007.06.004

Wood, D. J. 1991. Corporate social performance revisited. Academy of management review, vol. 16. no. 4, p. 691-718. https://doi.org/10.2307/258977

Yefimenko, T. I., Orlova, M. V., Pyetukhova, T. O. 2014. Podannya pokaznykiv sotsial'noyi vidpovidal'nosti pidpryyemnytstva $\mathrm{v}$ finansoviy zvitnosti. (Presentation of indicators of social responsible entrepreneurship in financial reporting. Effective Economics, no. 4. Available at: : http://www.economy.nayka.com.ua/?op=1\&z=2969. (In Ukrainian)

Zinchenko, A., Saprykina, M. 2017. Rozvytok KSV v Ukrayini: 2010-2018 (Corporate social responsibility development in Ukraine: 2010-2018). Kiev, Ukraine : Publishing House Yuston. (In Ukrainian)

\section{Acknowledgments:}

The publication of this article is supported by the Slovak Agency KEGA - Project KEGA 005SPU-4/2019 “Theory and Practice of the International Management and Entrepreneurship in Multicultural Environment", which is solved at the Department of Management in Poprad, Faculty of Education, Catholic University in Ruzomberok and the Department of Management, Faculty of Economics and Management, Slovak University of Agriculture in Nitra.

\section{Contact address:}

*Oksana Sokil, Slovak University of Agriculture, Faculty of Economics and Management, Department of Management, Trieda A. Hlinku 2, 94976 Nitra, Slovakia, Tel.: +421944 413793 ,

E-mail: oksanka.sokil@gmail.com

ORCID: https://orcid.org/0000-0002-8315-7403

Iveta Ubrežiová, Catholic University in Ružomberok, Faculty of Education, Department of Management, Nábrežie Jána Pavla II., č. 15, 05801 Poprad, Slovakia,

E-mail: iubreziova@gmail.com

ORCID: https://orcid.org/0000-0003-3681-1297

Teresa Eugenio, School of Technology and Management, CARME - Centre of Applied Research in Management and Economics, Polytechnic Institute of Leiria, Morro do Lena - Alto Vieiro, 2411-901 Leiria, Portugal,

E-mail: teresa.eugenio@ipleiria.pt

ORCID: https://orcid.org/0000-0003-1040-3164

Tânia Marques, School of Technology and Management, CARME - Centre of Applied Research in Management and Economics, Polytechnic Institute of Leiria, Morro do Lena - Alto Vieiro, 2411-901 Leiria, Portugal,

E-mail: tania.marques@ipleiria.pt

ORCID: https://orcid.org/0000-0003-0492-6233

Corresponding author: * 